\title{
EDITORIAL
}

\section{Gender, Parliament, Democracy and Time}

\author{
Anthoula Malkopoulou \\ Lund University, SE \\ anthoula.malkopoulou@svet.lu.se
}

This is the second issue with our new publisher, Helsinki University Press, and we could not be prouder for offering free online open access to all our articles without author fees. This fresh start for Redescriptions comes with a confirmation of its well-established intellectual focus. Our articles are unique in that they always combine two of three analytical angles: historical, political, and rhetorical. In this specific issue, the articles share two more characteristics. First, they tackle under-researched topics and explore hidden meanings that make them score high on originality points. And second, they all dig deep under the surface of philosophical thought and historical debates to extract their politics. As a result, the political meaning of ideas - Kant's and Weber's - and words - used by Swedish parliamentarians or the Finnish security police - becomes intelligible through a close reading of how the use of these ideas and words situates an agent within a political context.

The first two articles discuss canonical thinkers, focusing on little-known dimensions of their work. The two articles that follow belong to a different tradition, which has always been welcome in our journal, namely the politics of language.

The issue opens with an article combining feminist theory and history of political thought. The central theme in Lorenzo Rustighi's article is the patriarchal subtext of Kant's marriage contract. At first sight Kantian marriage appears egalitarian precisely because it is conceived as a contract between two equal partners. However, following the architecture of republican social contracts, and strongly influenced by Hobbes, Kant considers marriage a constituted unity that has a common will delegated to the sovereign head of the household. Therefore, male household leaders become invested with the power to interpret the couple's joint will and with the legitimacy to coerce women to abide to it. It is Hegel who, in Rustighi's view, uncovers this profound patriarchal substructure in Kant's thinking. Hegel is himself neither a champion of gender equality nor women's empowerment. But by recognizing gender differences and the ascription of roles on the basis of gender, he makes the concept of marriage more transparent and the possibility of transforming gender roles more conceivable.

Rustighi's article ultimately lays bare the political intricacies of philosophical thought. Political philosophers such as Kant often evade a critique of the presence or absence of bias in their theory, because their arguments appear to be analytically soundproof. However, the lack of gender sensitivity and justified assumptions about gender capacities and roles in Kant is striking. At the end, his whole theoretical construction of marriage equality crumbles under the weight of a strong underlying idea about male entitlement.

In Cristiana Senigaglia's text, it is Max Weber who is in the spotlight, particularly his littleknown views about direct democracy. Senigaglia expertly presents not only Weber's nuanced ideas about different types of direct democracy, but also how they are utilized in order to 
further strengthen Weber's support for parliamentarism. Several types of direct democracy are discussed and criticized by Weber. Citizen assemblies, selected by lot or governed by imperative mandate and recall procedures, have the fundamental weakness of blocking out expertise and specialisation, promoting dilettante rule and weakening popular power visa-vis the administration. Referenda are also bad as they increase polarisation; even worse, they simplify political options into a yes-or-no answer, which inhibits compromise, negotiation, and amendment. A third type, street democracy, increases chances of manipulation as it foregrounds emotions, and removes individual responsibility and the temporal room for reflection. Finally, plebiscitary democracy is for Weber paradigmatic of how the appreciation of charisma can shrink the role and rights of the people against an individual with unchecked powers. By contrast to all these types of direct democracy, parliament combines a limited use of charisma and the antiauthoritarian ambitions of direct democracy within an ordered legal framework.

Senigaglia's analysis mirrors the article by Rustighi in that it highlights the contemporary relevance of a historical figure in political thought. The aim is not as much to illuminate further the philosophical ideas of these authors for antiquarian purposes, but to discover and borrow their arguments for use in contemporary debates. In Rustighi's case, we learn that denying gender differences can carry on implicit patriarchal bias. Likewise, Senigaglia offers a nuanced response to contemporary populist appropriations of direct democracy by way of demonstrating the qualitative differences between a number of direct-democratic instruments and underlying the many disadvantages they carry vis-à-vis parliamentary democracy.

As with Senigaglia, parliament is also the centre stage of Anna Friberg's article. We are now transferred to the Swedish interwar years and to the parliamentary debates about democratisation in Sweden. The selected discussions are centred on three key aspects of democracy: the potential abolition of bicameralism, the possible introduction of referendum procedures, and proposals to abandon the monarchical form of government in favour of a republic. Drawing on Reinhart Koselleck, Friberg focuses on the perceptions and linguistic uses of time, which grant different argumentative weight to experiences and expectations respectively. In general, the communists who pressed for immediate democratization of government structures emerged as visionaries, who justified change as a demand from the future. By contrast, liberal conservatives, as expected, tended to highlight the wisdom of inherited traditions and the corresponding risks of jumping into untried novelties. For social democrats, neither the past nor the future had a commanding force as for the other two parties. Instead, their attention was more geared towards the present, which explained a constant split within their ranks between support for changes and a reluctance to implement them.

We learn from Friberg's article that parliamentary speakers often rely on specific temporal motifs to add strength to their argument. But relation with time is neither an empty decorum nor accidental; it is closely tied to the temporalities subsumed by different political ideologies, which interpret the value of history and the ideologues' role in it in light of their own experiences and expectations. Moreover, the effect of these distinct relations to time has profound effects on the strategic profile of a political party, as it conditions its radical, conservative or reformist nature.

The last article, by Kotonen, shares with Friberg an interest in the political effects of the use of certain linguistic terms. Here we travel to post-WWII Finland and the headquarters of the security police. The article develops a critique of how law enforcement used the terms 'fascism', 'Nazism', and 'far right' in quasi-arbitrary ways. A central influence in preferring one term over another was the Paris Peace Treaty signed between Finland and the Allies, which stipulated that Finland had to disband fascist organizations. Therefore, fascism was narrowly defined in connection with pre-war fascist and Nazi ideologies, the 
use of paramilitary violence associated with those historical ideologies, and attempts to violate the peace treaty. In addition, because of Cold War priorities, Finnish security police was much more geared towards monitoring far-left movements and activities, with the dire consequence of leaving serious developments in the neo-fascist activist scene unreported. This includes, for example, the launch of an actual far-right terror campaign in the 1970s, which unravelled right under the nose of the authorities. Noticeably, far-right organisations had themselves adjusted to the new exigencies and the security police's modus operandi and avoided self-identifying as fascists or keeping direct and explicit links to pre-war organisations.

Kotonen's article reminds us of how much power words can have, especially in the context of legal text and law enforcement. Not only can they push illegal organizations to be more secretive about their identities; they can also, importantly, affect the work of public security and police operations as such, often in negative ways, relaxing the ambition and scope of these operations. At the end, language is not simply a means of communication, but a gateway for framing and conceptualizing fundamental issues that affect actual practices in concrete ways.

Taken together, these four articles illuminate topics that have been at the heart of Redescriptions: gender, parliament, democracy, and time. Each of them offers endless possibilities of contention and alternative conceptualization. In this sense, this issue offers concrete and original perspectives of how gender, parliament, democracy, and time can be effectively and creatively re-described.

\section{Competing Interests}

The author has no competing interests to declare.

How to cite this article: Malkopoulou, Anthoula. 2020. "Gender, Parliament, Democracy and Time." Redescriptions: Political Thought, Conceptual History and Feminist Theory 23(1): 1-3. DOl: https://doi.org/10.33134/rds.331

Submitted: 22 June 2020 Accepted: 22 June 2020 Published: 13 July 2020

Copyright: (c) 2020 The Author(s). This is an open-access article distributed under the terms of the Creative Commons Attribution 4.0 International License (CC-BY 4.0), which permits unrestricted use, distribution, and reproduction in any medium, provided the original author and source are credited. See http://creativecommons.org/licenses/by/4.0/. 